\title{
MATERIALY DUSZPASTERSKIE
}

\section{Ks. Sianisław Wiodarczyk \\ MISTERIUM PASCHALNE PUNKTEM KULMINACYJNYM HISTORII ZBAWIENIA (refleksje egzegetyczno-teologiczne)}

\section{OBRAZ CIERPIĄCEGO MESJASZA}

Od chwili wyznania w Cezarei droga Jezusa zmierza ku męce i śmierci. Odtąd zaczął On otwarcie zapowiadać swoim uczniom, że musi cierpieć i umrzeć jako ofiara przeciwników. Wyrazem tego są liczne zapowiedzi męki u synoptyków. W trzeciej zapowiedzi męki u św. Eukasza 18, 31-33 uderza nas fakt powoływania się Jezusa na Proroków: ,Oto idziemy do Jerozolimy i spelni się wszystko, co napisali prorocy o Synu Człowieczym. Zostanie wydany w ręce pogan, będzie wyszydzony, zelżony i opluty; ubiczują Go i zabiją, a trzeciego dnia zmartwychwstanie. To powoływanie się na proroków ma na celu nawiązanie do historii i doświadczeń narodu wybranego i jego bohaterów, które znajdą dopełnienie w Jezusie.

Patrząc na historię zbawienia narodu wybranego, który oczekiwał na Mesjasza, widzimy, że w różnych etapach tejże historii różnie Go sobie wyobrażał. Idea Mesjasza cierpiącego zrodziła się w czasie ciężkich doświadczeń narodu wybranego. Powstawała ona powoli, aby trafić na sprzyjające warunki jej przyjęcia i rozwoju.

Niewola babilońska (586 r. przed Chr.), która była według proroków, zwłaszcza Ezechiela i Deutero-Izajasza, karą za podeptanie praw Przymierza, była również wielkim doświadczeniem narodu wybranego. Posłużyła ona Bożej Opatrzności, aby tej Reszcie Izraela, a przez nią całej ludzkości, przekazać niezwykłą obietnicę zbawienia przez poniżenie, cierpienie i śmierć Sługi Pańskiego - Mesjasza.

W związku z tym nasuwa się pytanie: na czym polegała zbawcza funkcja cierpienia Mesjasza (Sługi Pańskiego)?

Aby odpowiedzieć na powyższe pytanie, trzeba pokrótce zatrzymać się nad czwartą pieśnią Sługi Pańskiego (Iz 52, 13-53, 12), Zachariaszem 12, 10 oraz Psalmem 22.

W czwartej pieśni o Słudze Pańskim, ów Sługa jest przedstawiony jako cierpiący i całkowicie wyniszczony za cudze grzechy. To wyniszczenie stanowi akt zbawczy Boga, a jego kresem jest chwalebne wywyższenie Sługi i poddanie pod jego władzę wszystkich przez niego 
odkupionych. Sługa jest przeświadczony, że jego wyniszczenie prowadzi do zbawienia, przynosi pokój $(53,5)$, usprawiedliwienie $(53,11)$, wyzwolenie grzeszników i uwielbienie Boga $(53,11)$.

Właściwy cel i racje straszliwych cierpień Sługi są przedstawione w Iz 53, 5, gdzie czytamy: „Lecz On był przebity za nasze grzechy, zdruzgotany za nasze winy. Spadła Nań chłosta zbawienna dla nas, a w Jego ranach jest nasze zdrowie." $Z$ tekstu wynika, że ofiara Sługi ma charakter zastępczy. Sługa ów jest wybawicielem i orędownikiem. Przyjął cierpienie, aby Boga przebłagać za grzechy wszystkich ludzi. $\mathrm{Ta}$ ofiara cierpienia przyniesie wybawienie i uzdrowienie innych. Komentatorzy tego wiersza podkreślają, że po raz pierwszy w Starym Testamencie pojawia się wyraźnie sprecyzowana idea, iż jeden człowiek może przez swoje cierpienie dokonać ekspiacji za winy drugiego człowieka; więcej - za winy wszystkich ludzi, z tym, że to musi być człowiek Boży.

Sługa ów będzie musiał się podporządkować woli Bożej w doskonały sposób, co wyraża Iz 53, 7: „Dręczono Go, lecz sam dał się gnębić, nawet nie otworzył ust swoich. Jak baranek na rzeź prowadzony, jak owca niema wobec strzygących ją, tak On nie otworzył ust swoich."

O usprawiedliwiającej wartości cierpienia Mesjasza Pańskiego mówi nam również Zachariasz 12, 10: „Na dom Dawida i na mieszkańców Jeruzalem wyleję Ducha Pobożności. Będą patrzeć na tego, którego przebili i boleć będą nad nim, jak się boleje nad jedynakiem, i płakać będą nad nim, jak się płacze nad pierworodnym".

Abstrahując od dyskusji, które przynosi ten wiersz, komentatorzy godzą się, że w pierwszej części tego wiersza chodzi o obietnicę, że lud będzie wyczekiwał od Boga swojego zbawienia i będzie o nie prosił. To zbawienie przyniesie śmierć reprezentanta Jahwe.

Analogiczne cierpienie co Sługa Pański z pieśni Izajasza przeżywa bohater Psalmu 22, z tym, że u autora czwartej pieśni o Słudze Jahwe cierpienie, jak powiedzieliśmy wyżej, ma charakter wyraźnie zastępczy. Natomiast w Ps 22 związek przyczynowy między cierpieniem lamentującego, a uwolnieniem pogan nie występuje wyraźnie. Tę lukę dostrzega wielu autorów (A. Gelin). Autor Ps 22 rozważa przeszłe cierpienia i otrzymane po nich zbawienie. Zdaniem komentatorów Ps 22 zwraca baczniejszą uwage na temat „uniżenie i wywyższenie”, przedstawiające go jako charakterystyczny dla zbawczej działalności Bożej. Pomija prawie milczeniem prawdę o cierpieniu zastępczym. Faktycznie u szczytu historii zbawienia temat ,uniżenie i wywyższenie" okazal się w Jezusie jedną z podstawowych prawd.

To krótkie spojrzenie na teksty starotestamentalne może nasunąć pytanie - czy i jaki wpływ miały one na ewangeliczny opis męki Jezusa? Wielu egzegetów sądzi, że u podstaw chrześcijańskiej interpretacji męki i śmierci Jezusa znajduje się Izajaszowe proroctwo o cierpiącym Słudze Pańskim, które można nazwać protoewangelią 
męki Chrystusa. Kościół pierwotny widział w Jezusie Sługę Pańskiego, o czym może świadczyć pierwotne nauczanie (Dz), czy fragmenty hymnów chrześcijańskich o samowyniszczeniu i posłuszeństwie Jezusa (Flp 2, 6-11; 1 P 2, 21-25).

Sw. Eukasz w różnych swoich tekstach widzi w Izajaszowym Sludze Pańskim proroczą zapowiedź - typ samego Jezusa Chrystusa, Mesjasza i Zbawiciela. Już w Kantyku Symeona nawiązuje do proroctwa Izajasza 40,$5 ; 42,6 ; 46,13 ; 49,6 ; 52,10$ nazywając dziecię Jezus ,zbawieniem”. Kantyk jest również przykładem pierwszych w Nowym Testamencie sformułowan nauki o powszechnym odkupieniu: „światło na oświecenie pogan i chwałę ludu Twego, Izraela”.

Z czwartej pieśni Izajasza św. Łukasz bierze dosłownie: Iz 53, 12d (= Łk 22 37): „zaliczony został do złoczyńców” Prorok mówi tutaj, że lud uzna cierpiącego Sługę Pańskiego za równego tym, którzy buntują się przeciw Bogu, czyli łamią Jego prawo. Te słowa przypisuje św. Łukasz samemu Jezusowi, gdy po Ostatniej Wieczerzy zwiastuje On Apostołom początek swej męki.

Żaden inny fragment, tylko Iz 53 mógł inspirować. św. Łukasza, który stwierdza, że Mesjasz musiał cierpieć, aby wejść do swej chwały (Łk 24, 26). Ponadto Jezus używając tytułu Syn Człowieczy w powiązaniu ze swoją męką i śmiercią łączył ten tytuł z wątkiem Iz 53.

To łączenie tytułu Syna Człowieczego z męką i śmiercią Jezusa bardzo wyraźnie występuje u św. Łukasza w trzech zapowiedziach męki i zmartwychwstania Chrystusa (Łk 9, 22-25; 44, 45; 18, 31-33).

Proroctwo Izajasza o Słudze Pańskim stosują do Jezusa również Dzieje Apostolskie. Sw. Piotr w swojej drugiej mowie, po uzdrowieniu chromego, skierowanej do ludu zebranego w krużganku Salomonowym powiedział: „Bóg naszych ojców, Bóg Abrahama, Izaaka i Jakuba, wsławił Sługę swego, Jezusa, wy jednak wydaliście Go i zaparliście się Go przez Piłatem, gdy postanowił Go uwolnić" (Dz $3,13)$.

Proroctwo o Słudze Pańskim stosowano do Jezusa dlatego, że

1) było zgodne $z$ nauczaniem Jezusa znanym $z$ ewangelii,

2) mogło oddać nieocenione usługi w nauczaniu apostolskim w środowisku judaistycznym.

Uderza nas również to, że nazwa pais Theou zastosowana do Jezusa nie jest znana w żadnej księdze Nowego Testamentu, tylko w Dziejach Apostolskich.

Silne podkreślenie męki Jezusa, sugeruje nam, że św. Piotr uważał Go za nowego Sługę Bożego, o którym mówił prorok Izajasz.

W Dz 8, 32-35 św. Eukasz cytuje urywek z księgi Iz 53, 7-8, z tym, że cytuje go za Septuagintą, z pominięciem zwrotów, które ukazują soteryjne wartości cierpienia Jezusa. Ale te zmiany wprowadzone w Septuagincie pozwoliły Filipowi nawiązać do Jezusa (w. 33a), do Jego krzyża, a w w. 33c do Jego zmartwychwstania. Św. Eukasz nie przekazał nam szczegółów interpretacji Filipa. Ale kontekst wska- 
zuje, że Filip interpretował cały ten urywek z proroka Izajasza, jako tekst mesjański i odnosił do Jezusa, Jego śmierci i zmartwychwstania.

Takie porównania mogłyby nasunąc czytelnikowi pewną wątpliwość, a mianowicie, czy przypadkiem św. Eukasz nie układał opisu męki według starotestamentalnych zapowiedzi proroków, a zwłaszcza czwartej pieśni o Słudze Pańskim lub czy te starotestamentalne teksty nie determinowały życia i męki Chrystusa?

Jedno musimy na początku stwierdzić, iż zestawiając opis męki Jezusa $\mathrm{z}$ wyżej wspomnianymi tekstami starotestamentalnymi uderza nas podobieństwo idei. Tak teksty starotestamentalne, jak opis ewangeliczny w cierpieniu i śmierci Bożych wybrańców ukazują akt ekspiacyjny za grzechy wszystkich ludzi, jako źródło pojednania z Bogiem i odrodzenia dọ nowego życia. U św. Eukasza 19, 10 czytamy: „Albowiem Syn Człowieczy przyszedł szukać i zbawić to, co zginęło”.

Różnica między opisami starotestamentalnymi a ewangelicznym opisem męki Jezusa jest właściwie jedna, a mianowicie, iż zbawcza wola Boża, co dają jasno do zrozumienia ewangelie, jest równocześnie własną wolą Jezusa:

Św. Eukasz zauważył w życiu Jezusa spelniające się zapowiedzi mesjańskie Starego Testamentu, ale nie według nich układał opis męki Jezusowej, one nie determinowały życia i męki Jezusa, lecz w Jego słowach i czynach znajdowały swe urzeczywistnienie.

\section{MĘKA I SMIERĆ JEZUSA DLA ZBAWIENIA WSZYSTKICH LUDZI (Ek 3,6)}

Idea, iż jeden człowiek może przez swoje cierpienie i śmierć dokonać ekspiacji za winy drugiego, więcej - za winy wszystkich ludzi, z tym, że musi to być czlowiek Boży, pojawia ısię po raz pierwszy w Starym Testamencie u Iz 53,5. Na ogół misja dokonania czegoś wielkiego przez cierpienie i śmierć była dla Żydów czymś niezrozumiałym. Znana była, biorąc $\mathrm{z}$ punktu czysto naturalnego, w filozofii greckiej i w świecie rzymskim.

W historii Grecji znaleźć można opowieści o ludziach, którzy umarli za swoje państwo czy za naród. Najbardziej wzruszającą śmiercią w literaturze greckiej jest śmierć Sokratesa opisana przez Platona. Ale jego śmierć nie była częścią Bożego planu zbawienia. Również Rzymianie mieli swe opowieści i legendy o bohaterach, którzy umarli broniąc Rzymu.

$\mathrm{Na}$ skutek niezrozumienia przez Żydów idei męki i śmierci dla czegoś wielkiego, w pierwotnym Kościele uznano za konieczność oprzeć tę ideę na wyraźnych źródłach biblijnych, które wykazywałyby, że misja Jezusa została zaplanowana przz Boga i była zgodna $z$ jego wolą. Stąd nas nie dziwi, że św. Łukasz często odnosi się do tekstów Starego Testamentu. Również Jezus Chrystus wiele razy odwołuje 
się do proroctw Starego Testamentu, twierdząc, że cierpi za innych i dla dobra innych ( $1 \mathrm{k} 22,14-20$ ):

Męka i śmierć Jezusa w ujęciu św. Łukasza jest włączona w cały plan zbawienia. Stąd nie jest tak jasno akcentowany jej zbawczy charakter, gdyż cała działalność Jezusa ma charakter zbawczy. Wypełnia On ten plan podczas całej tylko jednej z jego epizodów, a przez to nie wybija się tak mocno jak u św. Pawła, który jedynie jej przypisuje znaczenie soteriologiczne.

Św. Eukasz patrzy na śmierć i zmartwychwstanie Jezusa Chrystusa w kategoriach teologicznych, stąd jak widzieliśmy, jego pierwszą troską jest ustawienie śmierci i zmartwychwstania w długim łańcuchu zapowiedzi.

Smierć Jezusa stanowi akt centralny tajemnicy zbawienia, która ma swój klucz w zmartwychwstaniu i wywyższeniu Mesjasza. Śmierć jest konieczna $\mathrm{z}$ punktu widzenia Bożego planu zbawienia. Jezus umiera, ponieważ to jest wolą Bożą: „Ojcze, jeśli chcesz, zabierz ode mnie ten kielich! Jednak nie moja wola, lecz Twoja niech się stanie." (Łk 22, 42) To wypełnienie się woli Bożej jest podkreślone przez ostatnie słowa Jezusa; który cytuje Ps 31 (30), 6; „Ojcze, w Twoje ręce powierzam ducha mojego" (Ek 23, 46). Dramat śmierci posiada dwa wymiary: zwycięstwo nad nieprzyjaciółmi i ustanowienie nowego Ludu Bożego.

Niektórzy autorzy twierdzą, że św. Eukasz nie podjął wyraźnie tematu zadośćuczynnej śmierci Jezusa dlatego, że liczył się z odbiorcami ewangelii, którym ta koncepcja była obca. Natomiast nawiązał do idei wzoru znanej światu greckiemu i hellenistycznemu i nadał jej chrześcijański sens. Stąd mówi o ciągłym niesieniu krzyża (主k 9, $23 ; 23,26)$.

Tylko św. Łukasz podkreśla, co jest charakterystyczne dla niego, zbawcze działanie krzyża wobec pokornej postawy wierzącego. Tę zbawczą moc Krzyża podkreśla autor trzeciej ewangelii poprzez wspomnienie świadków, którzy, ,gdy zobaczyli, co się działo, wracali bijąc się w piersi" (Łk 23, 48) A setnik, „na widok tego, co się działo, oddał chwałę Bogu i mówił: Istotnie, człowiek ten był sprawiedliwy." (乇k $23,47)$.

Rodzi się pytanie, zresztą bardzo trudne i do tej pory nierozwiązane przez teologów i egzegetów, czy i w jakim stopniu św. Eukasz towarzysz św. Pawła, był zależny w kwestii ujmowania zbawienia, a w związku $z$ tym męki i śmierci, od apostoła narodów?

Już od czasów pisarzy chrześcijańskich mówi się ogólnie, że św. Łukasz wziął od Pawła główne idee. Tertulian mówił, że św. Paweł był tym, który oświecał św. Łukasza, który od apostoła narodów wziął główne idee. Egzegeci i teologowie podkreślają bliskie podobieństwo między opisem ustanowienia Eucharystii u św. Eukasza i św. Pawła.

$\mathrm{Na}$ podstawie podobieństwa idei można powiedzieć, że św. Eukasz przejmuje od św. Pawła uniwersalizm nauki o zbawieniu. Ta uniwer- 
salistyczna myśl o zbawieniu przewija się na wielu miejscach w dziele św. Łukasza. I tak cytując proroka Izajasza mówi: „I wszyscy ludzie ujrzą zbawienie Boże” (Łk 3, 6), a dalej powie: „Albowiem Syn Człowieczy przyszedł szukać i zbawić to, co zginęło" (Łk 19, 10). Na początku Dziejów Apostolskich, kreśląc misję zbawczą Kościoła, mówi, że dosięgnie ona „krańców ziemi”. Mimo że św. Łukasz umieszcza mękę i śmierć Jezusa w kontekście całego planu zbawienia, to jednak w samej strukturze ewangelii ona się uwidocznia. Jezus rozpoczynając swą działalność w Galilei, kieruje się ciągle ku Jerozolimie, gdzie będzie miał miejsce szczyt planu zbawienia. To dążenie ku Jerozolimie zacząl już św. Łukasz lekko w pierwszej części ewangelii, potem uwydatnia coraz bardziej, aż w ostatniej części życie Jezusa łącznie z męką i uwielbieniem umieszcza w Jerozolimie. Dwie charakterystyczne wypowiedzi św. Łukasza wskazują na to dążenie Jezusa ku Jerozolimie i wypełnienie tego co zapowiedzieli prorocy:

1. „Jednak dziś, jutro i pojutrze muszę być w drodze, bo rzecz niemożliwa, żeby prorok zginął poza Jerozolimą" (Ek 13, 33);

2. „Potem wziąl Dwunastu i powiedział do nich: Oto idziemy do Jerozolimy i spełni się wszystko, co napisali prorocy o Synu Człowieczym" ( $\mathrm{kk} \mathrm{18,31).}$

Gdy weźmiemy śmierć Jezusa w kontekście żydowskiej Paschy, to widzimy, że św. Łukasz łączy Paschę Jezusa z Paschą żydowską: „Tak nadszedł dzień Przaśników, w którym należało ofiarować Paschę. Jezus posłał Piotra i Jana $z$ poleceniem: Idźcie i przygotujcie nam Paschę, byśmy mogli ją spożyć" (Łk 22, 7-8); dalej dodaje: „Gorąco pragnąłem spożywać tę Paschę z wami, zanim będę cierpiał. Albowiem powiadam wam. Już jej spożywać nie będę, aż się spełni w królestwie Bożym" (૯k 22, 15-16).

To nawiązanie do Paschy żydowskiej nie było bez znaczenia. Tamto święto było pamiątką wyjścia $z$ niewoli egipskiej, było ono również zapowiedzią uwolnienia całej ludzkości z niewoli grzechu.

Już wczesna tradycja chrześcijańska dostrzegała wypełnienie się starotestamentalnej Paschy w śmierci Jezusa. Bardzo wyraźnie widzimy to u św. Pawła i u św. Jana.

Św. Paweł w 1 Kor 5, 7 pisze: „Chrystus bowiem został złożony w ofierze jako nasza Pascha". Tutaj św. Paweł nie daje żadnych wyjaśnień, co świadczy, że jest to rzecz znana.

A św. Jan powie: „Stało się to bowiem, aby się wypełniło Pismo: Kość jego nie będzie złamana. I znowu na innym miejscu mówi Pismo: Będą patrzeć na Tego, którego przebili" (19, 36-37).

To porównanie Jezusa $\mathrm{z}$ barankiem paschalnym u św. Pawła i Jana było wyrazem przekonania, że dzień i godzina śmierci Jezusa zbiega się $z$ żydowskim obrzędem zabijania baranka $w$ świątyni w czasie święta Paschy. Obydwaj dostrzegli, że typologia paschalna wypełnia się $\mathrm{w}$ czasie śmierci Jezusa. Jezus jest więc „Barankiem, który gładzi grzechy świata" (J 1, 29). 
Pomimo że św. Łukasz nie podkreślał wyraźnie soteriologicznego charakteru męki i śmierci Jezusa, to o jej zbawczym charakterze świadczy służebny charakter całego Jego życia (Łk 22, 27). Cała droga Jezusa prowadziła do Jerozolimy, aby tam osiągnąć swój centralny punkt.

\section{ZMARTWYCHWSTANIE CHRYSTUSA DOPEENIENIEM DZIEŁA ZBAWIENIA}

Naszym celem nie jest tylko przedstawierie faktu zmartwychwstania Chrystusa w dziele św. Eukasza, czy przytaczanie najnowszych na ten temat rozwiązań egzegetyczno-teologicznych, lecz przede ws zystkim ukazanie wymiaru soteriologicznego zmartwychwstania, jego ścisłego związku ze śmiercią Jezusa Chrystusa (dziełem odkupienia), gdyż do niedawna w teologi $i_{\perp}$ traktacie o Odkupieniu nie było właściwie miejsca na rozważanie o fakcie zmartwychwstania jako zbawczym misterium. Dołączano zazwyczaj krótką wzmiankę o zmartwychwstaniu jako osobistym triumfie Chrystusa oraz zasłużonej nagrodzie za uniżenie, cierpienie i śmierć. W ten sposób zmartwychwstanie Chrystusa jako misterium zbawcze zostało pozbawione swego głębokiego wymiaru soteriologicznego.

Dopiero w ostatnich dziesiątkach lat bibliści i teologowie zwrócili uwagę na ten bardzo ważny wymiar zmartwychwstania i jego ścisłego związku z dziełem odkupienia. Również reforma liturgii. a zwłaszcza paschalnej, oraz reforma Wielkiego Tygodnia (Dekret Kong. Obrzędów z 16. XI. 1955) zwróciły uwagę na organiczną jedność śmierci i zmartwychwstania Chrystusa. A Sobór Watykański II przywrócił misterium paschalnemu jego centralne miejsce w historii zbawienia (Konst. o Liturgii, Konst. o Kościele). Również ostatni papieże zwrócili uwagę na zbawczy wymiar zmartwychwstania Chrystusa. I tak papież Paweł VI w swoim przemówieniu wygłoszonvm : Wigilię Wielkanocną (13. IV. 1966) powiedział: „Mówimy - umar dla nas. Natomiast nie jesteśmy przyzwyczajeni uważać zmartwychwstania Pańskiego za fakt odnoszącỳ się do nas. W naszej pobożności, jak tęz w naszej nauce, nie nadajemy zmartwychwstaniu Chrystusa tego znaczenia soteriologicznego, które mu przyznać należy. A papież Jan Paweł II w encyklice Dives in misericordia pisze: „W zmartwych wstaniu Chrystus objawił Boga miłnści miłosiernej przez to właśnie, że jako drogę do zmartwychwstania przyjął krzyż" (n. 8).

Po tych uwagach wprowadzających $\mathrm{w}$ problem zagadnienia pytamy - jak św. Eukasz w swoim dziele patrzy na fakt zmartwychwstania Chrystusa?

Aby odpowiedzieć na to pytanie musimy pamiętać o tym, że fakty zbawcze umieszcza on $\mathrm{w}$ całym kontekście historii zbawienia, stąd odwołuje się do tekstów Starego Testamentu: Również w wypadku 
zmartwychwstania idzie tą drogą. Już w zapowiedziach męki, a szczególnie trzeciej zapowiedzi ( $\mathrm{Ek} 18,31-32$ ), oraz $\mathrm{w}$ scenie rozmowy Chrystusa zmartwychwstałego z uczniami idącymi do Emaus (Łk 24, 25-27), łączy św. Eukasz mękę, cierpienia i śmierć z faktem zmartwychwstania, powołując się przy tym na Pisma. W rozmowie z uczniami idącymi do Emaus ujawnia się to szczególnie: „O, nierozumni, jak nieskore są wasze serca do wierzenia we wszystko, co powiedzieli prorocył Czyż Mesjasz nie miał tego cierpieć, aby wejść do swojej chwały? I zaczynając od Mojżesza poprzez wszystkich proroków wykładał im co we wszystkich Pismach odnosiło się do Niego" (壬k 24, 25-27). A skoro tak, to musimy pokrótce zapytać, jak przedstawia się idea zmartwychwstania w Starym Testamencie, a szczególnie zapytać czy mamy jakieś reminiscencje, że Cierpiący Mesjasz (Sługa Jahwe) zmartwychwstanie?

$\mathrm{Na}$ początku musimy jedno stwierdzić, że Stary Testament w początkowej fazie rozwoju koncepcji teologicznej nie kreśli wyraźnie idei przyszłgo zmartwychwstania. Umarli są daleko od Boga. Stąd też nie dziwi nas, że motyw „śmierci” za kogoś nie doznawał pozytywnego naświetlenia. Chcąc choć po krótce nakreślić ten problem, który pozwoli nam zrozumieć myśl św. Łukasza i wpływ tychże idei na jego koncepcje zmartwychwstania, trzeba nawiązać chociaż do niektórych idei starotestamentalnych i niektórych tekstów Starego Testamentu.

W spojrzeniu na ten problem trzeba uwzględnić dwa okresy myśli: 1) myśl semicką $w$ znaczeniu ścisłym, tj. tą, jaką wskazują nam teksty biblijne do roku 250 przed Chrystusem,

2) myśl hellenistyczną, którą się wyczuwa w dziełach judaizmu palestyńskiego mówiącego językiem aramejskim lub hebrajskim.

Do II wieku przed Chrystusem Izrael nie posiadal jasnej doktryny odnośnie zmartwychwstania zmarłych. Wiarę, która przetrwała 2 tysiące lat historii świętej- od Abrahama aż do rewolty Machabejskiej, można by $\mathrm{w}$ wielkim skrócie tak streścić: człowiek nie jest, jak u Greków, duszą zjednoczoną z ciałem (materią). Ciało nie jest czymś zdegradowanym, lecz jest bytem stworzonym przez Boga na swój obraz i podobieństwo. I ten byt nie ginie wraz ze śmiercią, lecz schodzi do szeolu, miejsca podziemnego, gdzie znajduje wszystkich zmarłych bez rozróżnienia sprawiedliwych i bezbożnych.

W II wieku przed Chrystusem sytuacja zmienia się diametralnie. $\mathrm{Na}$ pewno było wiele przyczyn, w które tu wchodzić nie będziemy. W pierwszym rzędzie to hellenizacja i prześladowania za czasów Antiocha IV Epifanesa. To wszystko pociąga za sobą zmianę mentalności i poglądów.

Spojrzymy teraz pokrótce na teksty biblijne, które wiążą się z poszczególnymi okresami myśli żydowskiej.

Ogólnie możemy powiedzieć, że myśl o zmartwychwstaniu istnieje w literaturze prorockiej. Najdobitniej wyraził ją Ezechiel 37, mówiąc o przywróceniu do życia przez Jahwe przebywającego w niewoli na- 
rodu, a więc znajdującego się niejako w stanie śmierci. Ta monumentalna wizja kości powracających do życia pod wpływem natchnionych słów proroka podkreśla nie tylko wszechmoc Bożą, ale zakłada możliwość odwrócenia procesu śmierci.

Jeszcze dalej, idzie apokalipsa Izajasza, która mówi nie tylko o przezwyciężeniu i zniszczeniu śmierci (Iz 25, 8), ale o zmartwychwstaniu zmarłych: „Ożyją Twoi umarli, zmartwychwstaną ich trupy, obudzą się i krzykną z radości spoczywający w prochu, bo rosa Twoja jest rosą światłości, a ziemia wyda cienie zmarłych" (Iz 26, 19).

A w czwartej pieśni o Sludze Jahwe, gdzie dochodzi do glosu myśl o zastępczej śmierci, gdzie Sługa ów dobrowolnie uczynił siebie ofiarą całopalna za grzechy, czy on zmartwychwstanie?

Analizując tekst Iz 53, 10-13, można z pewnością utrzymywać, że autor czwartej pieśni o Słudze Pańskim ma na myśli zmartwychwstanie owego Sługi.

Przechodząc do tekstów z drugiego okresu myśli żydowskiej, tj. do II wieku przed Chrystusem, oprócz księgi Daniela, w której sprawa zmartwychwstania jest faktem oczywistym: „Wielu zaś, co posnęli w prochu ziemi, zbudzi się: jedni do wiecznego życia, drudzy ku hańbie, ku wiecznej odrazie" (12, 2), I i II Machabejskiej, Mądrości, echa zmartwychwstania znajdujemy również w księgach apokryficznych, z tym, że nie zawsze jasno się wyrażają.

Konkludując naszą myśl, nasuwa się pytanie, czy można znaleźć w dziele św. Łukasza jasne związki między zmartwychwstaniem a śmiercią zbawczą Chrystusa, jak to ma miejsce u św. Pawła (Rz $4,25)$,

Analiza tekstów z ewangelii i z Dziejów Apostolskich wskazuje, że św. Eukasz łączył prawdę o śmierci ofiarnej Chrystusa z Jego zmartwychwstaniem i odzyskaniem odpuszczenia grzechów przez tych, którzy uwierzyli i przyjęli chrzest. 